\title{
A systemic analysis of the usage of safety items among Malaysian private vehicle
} users

\author{
Z.M. Jawi ${ }^{1, *}$, M.H.M. Isa ${ }^{1}$, N. Mohamed ${ }^{2}$, A. Awang ${ }^{3}$ and M.R. Osman' \\ ${ }^{1}$ Vehicle Safety \& Biomechanics Research Centre, Malaysian Institute of Road Safety \\ Research (MIROS), 43000 Kajang, Selangor, Malaysia \\ *Email: zulhaidi@miros.gov.my \\ Phone: +60389249200; Fax: +60387364140 \\ ${ }^{2}$ Environmental Health Unit, Disease Control Division, Ministry of Health Malaysia \\ $(\mathrm{MOH}), 62590$ Putrajaya, Malaysia, \\ ${ }^{3}$ Driver Licensing Division, Road Transport Department (RTD), 62100 Putrajaya, \\ Malaysia
}

\begin{abstract}
In such a large road transportation system, human factor plays a very significant role in ensuring a desirable balance between transport demand and safe operations. This paper presents a systemic analysis of three safety items, namely seatbelt for adult car occupants, child safety seats (CSS) for young occupants and helmet for motorcyclists, of which the success level is highly reliant on the road users' willingness to utilise them according to the recommended and proper usage. In a temporal view of road crashes, these safety items were part of 'during-crash' passive safety components i.e. to provide protection during the crash impact phase. This analysis includes the safety items benefits and issues, related road safety strategic programmes, current legal framework, and local research findings based on observational studies. The use of both helmet and seatbelt was mandatory but the move has so far produced mixed results. Meanwhile, CSS usage and acceptance are on the rise, although still at a nascent stage. This situation can be considered as 'below satisfactory compliance level', hence a more inclusive solution is needed, including the introduction of technology, to influence or compel road users to wear such safety items while on the road.
\end{abstract}

Keywords: Road safety; safety items usage; motorcycle helmet; seatbelt; child safety seat (CSS).

\section{INTRODUCTION}

Road traffic accident is a global pandemic that has taken lives of more than a million road users annually. On average 3,500 people are killed each day and as one of the riskiest countries according to internationally comparable indices, Malaysia contributes between 15 to 20 to that fatality figures every single day $[1,2]$. The country had experienced a four percent growth in average road deaths during the eighties, which then increased to five percent in the nineties [3]. The period from 2000 to 2009 saw a decline by two percent but the actual number of road deaths fluctuated between 6,500 and 7,000. In 2010, 6,872 fatalities were recorded, marking a two percent increase from 2009 (6,745); whereas 
6,915 fatalities were recorded in 2013 - a mere reduction of two deaths as compared to $2012(6,917)[4]$. The most recent statistics indicated a decrease in the number of fatalities (6,674 in 2014), although the number rose again in the following year (6,706 in 2015) [5]. The abovementioned scenario of road traffic injuries and fatalities has posed a serious public health challenge to Malaysia. The Malaysian Government has conceptually introduced comprehensive actions in all areas of road transport including road safety, with a decent road infrastructure and vehicles ecosystem that the country can offer $[6,7]$. Nevertheless, we have yet to see the anticipated or 'acceptable' results. Both motorcyclists and car users continue to contribute up to 80 percent to the fatality rate, with the former consistently contributing 55 to 60 percent annually, thus becoming the country's biggest problem $[3,5]$. Therefore, the authors intend to revisit the bigger picture in the aspect of human errors in Malaysia's road safety context. Moreover, the specific objective of this review is to explain road users' attitude towards safety items while on the road, whereby decision to use the safety items or otherwise lies in their hands.

Seriousness of the Problem: Some fifty years ago, carmaker Volvo of Sweden introduced the modern form of three-point seatbelt that we use today as standard equipment, and many studies have confirmed its importance in protecting car occupants in vehicular crashes [8]. Development of child safety seat (CSS) as part of the child restraint system (CRS) in cars also shares the same objective although absolute compliance poses a different challenge [9]. Similarly, helmet for motorcyclist although a vital protective gear, may be the last thing on most people's mind in the event of a motorcycle crash [10]. Though these safety items are easily available in Malaysia, users are still lacking in attitude and awareness of their importance in saving lives. Nevertheless, since the implementation of rear seatbelt law in 2009, it is safe to say that the majority of cars on Malaysian roads today are equipped with seatbelts for all designated seats [11]. In contrast, the usage of CSS has yet to be made mandatory and creates a mixed situation regarding users' acceptance or willingness to abide by the law and the need to enact the law immediately [12]. Helmet wearing by motorcyclists, in addition, is still a major issue in the country since this group is the most vulnerable according to the casualty figures; yet the compliance rate of helmet wearing and proper usage is still a big challenge to relevant stakeholders $[13,14]$.

\section{METHODS AND MATERIALS}

As mentioned above, this review aims to explain the current situation on the usage of vital safety items for private vehicle users through a systemic point of view encompassing usage benefits and issues, related strategic programmes, current legal framework, and the findings from related local research based on observational method. The authors had compiled and analysed relevant published materials in order to explain the conceptual framework and status quo of road users' behaviour towards the usage of seatbelt and CSS for car users, and helmet for motorcyclists. In the temporal view of road crashes as suggested by the Haddon matrix, these safety items are working as passive safety, offering on-demand protection when a crash or impact occurs (Figure 1). The similarity among these safety items is that the users need to have them worn as safety measures if they get involved in road crashes. Other than seatbelt that has been fitted in the car, users apparently need to buy CSS for a child car occupant and such is the case for motorcycle helmet. 


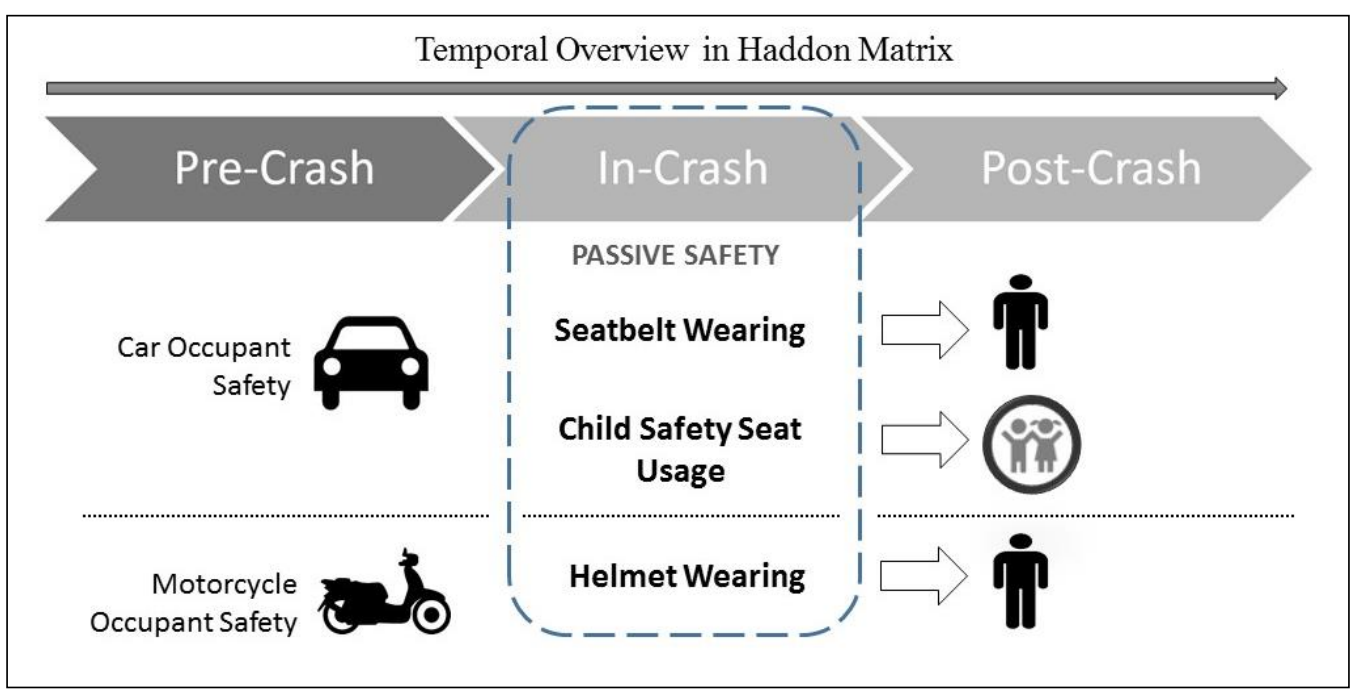

Figure 1. Conceptual framework of safety items usage based on Haddon Matrix.

Moreover, it is worth to note that the Royal Malaysian Police (RMP) plays a major role in road accident data collection in the country but statistics alone could not offer other perspectives on road traffic accidents [15]. Besides RMP's data, there are also other sources of road accident related records [16]. They are either collected by various government agencies or private entities including road accident data collection by highway concessionaires; real-world crash investigation reports by MIROS; rescue records by Fire \& Rescue Department of Malaysia (JBPM); injury data obtained by hospitals (Ministry of Health); insurance companies; and research conducted by universities and other relevant bodies. The observational studies which are mostly published by universities as well as the Malaysian Institute of Road Safety Research (MIROS) were chosen as the highlight of this systemic review because they presented a more genuine situation of road users' everyday scenario. However, it is also worth to note that certain studies are not totally comparable to each other due to many factors including time/year of study, sampling method, areas covered, etc.

\section{RESULTS AND DISCUSSION}

\section{Usage Benefits and Issues}

Related studies around the world have emphasised the importance and effectiveness of these safety items, though one might argue on their disadvantages such as ease-of-use, socio-economic and socio-technical issues [17]. Table 1 lists the findings of various researches on the benefits of using and issues of such safety items.

\section{Road Safety Strategic Programmes}

MIROS' founder, the late Dr. Radin Umar Radin Sohadi, during the early days of the institute in 2007, had outlined eight strategic programmes to be carried out across Malaysia to reduce road casualties [18, 19]. These programmes are divided into four categories, namely Enforcement (C1), Infrastructure (road engineering) (C2), Advocacy and Education (C3), and Vehicle Safety (C4). They were supposed to reduce about a quarter of the sub-7,000 annual fatalities by the end of 2010. Unfortunately, most of these intermediate programmes ( 3 to 5 years) was not able to "close-the-loop" due to many challenges during the implementation phase (Table 2) [20]. One of the reasons is because 
these projects require all relevant stakeholders including road users to support the systemic solutions. The programmes listed in Table 2 highlight the overwhelming issues including road users' low willingness to be protected on the road through the use of safety items for motorcyclist and car occupants, including for children (relating to P2, P5 and P6).

Table 1. Benefits of using and issues regarding safety items for vehicle occupants.

\begin{tabular}{|c|c|}
\hline Safety Item & Usage Benefits \& Issues \\
\hline $\begin{array}{l}\text { Seatbelt } \\
\text { (car) }\end{array}$ & $\begin{array}{l}\text { Benefits: } \\
\text { - Seat belts reduce the risk of fatal injury by } 30-40 \% \text {, depending on the } \\
\text { position in the passenger car [21]: } \\
\text { a. Reduce fatality risk among front passengers by } 45-50 \% \text { [22]. } \\
\text { b. Reduce fatality risk among rear passengers by } 25-75 \% \text { [23]. } \\
\text { - Most effective in frontal crash, reduce risk of death/serious injury by } 50 \% \\
\text { for driver \& front passenger [24]. } \\
\text { - Shimamura study: from unbelted to belted, fatalities/severe injuries reducer } \\
\text { by } 45 \% \text {; no. of vehicles with killed/injured occupants decrease by } 25 \% \text { for } \\
\text { drivers and } 28 \% \text { for front passengers [25]. } \\
\text { Issues: } \\
\text { - Rear seatbelt wearing rate e.g. [22]. } \\
\text { - Pregnant occupants e.g. [26]. } \\
\text { - The effectiveness of seatbelt reminder (SBR) e.g. [27]. }\end{array}$ \\
\hline $\begin{array}{l}\text { CSS } \\
\text { (car) }\end{array}$ & $\begin{array}{l}\text { Benefits: } \\
\text { - Child restraints reduce fatality risk up to } 50 \% \text { [21]. } \\
\text { - Associated with } 28 \% \text { reduction in death risk on children aged } 2 \text { to } 6 \text { if } \\
\text { not grossly misused [28]. } \\
\text { - NHTSA (USA) estimated that child restraints reduce fatality risk by } \\
\text { - } 71 \% \text { for infants \& } ~ 54 \% \text { for toddlers [29]. } \\
\text { - Back seat positioning: } \\
\text { a. Reduce significant injuries by } 40 \% \text { [30]. } \\
\text { b. Reduce risk of death by } 39 \% \text {, and risk of death \& serious injury by } \\
\quad 33 \% \text { [31]. } \\
\text { Issues: } \\
\text { - Inconsistent usage of CSS for many reasons e.g. [32]. } \\
\text { - Vehicle design to support usage e.g. seat curvature and posture, seatbelt } \\
\text { type, airbag. } \\
\text { - Placement in front of airbag, inside deployment zone is very dangerous } \\
\text { - } 333] \text { Attachment type e.g. top tether, ISOFIX. }\end{array}$ \\
\hline $\begin{array}{c}\text { Helmet } \\
\text { (motorcycle) }\end{array}$ & $\begin{array}{l}\text { Benefits: } \\
\text { - } 1943 \text { study: } 32 \% \text { of acute head injury cases used helmets compared to } \\
68 \% \text { who did not [34]. } \\
\text { - Proper helmet use reduces the risk of head injuries by } 69 \% \text { and fatalities } \\
\text { by } 42 \% \text { [35]. } \\
\text { - Un-helmeted motorcyclists were two times more likely to sustain head } \\
\text { injury compared to helmeted motorcyclists [36]. } \\
\text { Issues: } \\
\text { - Wearing rate, proper usage, and non-standard helmet e.g. [13]. } \\
\text { - Minimum age for child to become the pillion, thus creating issue of } \\
\text { "child helmet" [13]. }\end{array}$ \\
\hline
\end{tabular}


Table 2. Road safety strategic programs and status (As adapted from [18-20]).

\begin{tabular}{|c|c|c|}
\hline Category & Program & Description/Status \\
\hline \multirow{2}{*}{$\begin{array}{c}(\mathrm{C} 1) \\
\text { Enforcement }\end{array}$} & $\begin{array}{l}\text { (P1) Automated } \\
\text { Enforcement } \\
\text { System (AES) }\end{array}$ & $\begin{array}{l}\text { - Proposed enforcement: speeding, red light running } \\
\text { \& lane discipline. } \\
\text { - Had attracted public uproar during the pilot phase } \\
\text { in } 2012 \text { and national rollout has been postponed. } \\
\text { - Change of the appointed service provider; new } \\
\text { plan of national rollout. }\end{array}$ \\
\hline & $\begin{array}{l}\text { (P2) Rear } \\
\text { Seatbelts }\end{array}$ & $\begin{array}{l}\text { - Law introduced in January } 2009 \text {. } \\
\text { - } \text { Retrofitting campaign by car manufacturers; and } \\
\text { standard fit for new cars is ensured via Vehicle } \\
\text { Type Approval (VTA) by Road Transport } \\
\text { Department (RTD). } \\
\text { - Low usage rate/awareness (to be discussed). }\end{array}$ \\
\hline $\begin{array}{c}(\mathrm{C} 2) \\
\text { Infrastructure }\end{array}$ & $\begin{array}{l}\text { (P3) Motorcycle } \\
\text { Lanes }\end{array}$ & $\begin{array}{l}\text { This initiative is highly dependent on costing } \\
\text { issues - federal roads, state \& local authorities, } \\
\text { highway concessionaires - either for new or } \\
\text { existing roads. } \\
\text { - Safety and convenience issues pose a valid concern } \\
\text { among users. }\end{array}$ \\
\hline $\begin{array}{l}\text { Both }(\mathrm{C} 1) \& \\
\quad(\mathrm{C} 2)\end{array}$ & (P4) Black spots & $\begin{array}{l}\text { - Study/analysis to determine specific road stretches } \\
\text { where road crashes often occurred. } \\
\text { - Primarily based on road accident database. } \\
\text { - Helps prioritisation in road design improvement } \\
\text { and enforcement. }\end{array}$ \\
\hline $\begin{array}{l}\text { (C3) Vehicle } \\
\text { Safety }\end{array}$ & (P5) Airbags & $\begin{array}{l}\text { - The initial target is to standardise the fitment of } \\
\text { airbags with the intention to initiate New Car } \\
\text { Assessment Programme (NCAP). } \\
\text { - Fitment was gradually enforced in VTA. } \\
\text { - ASEAN NCAP was established in } 2011 \text { covering } \\
\text { both passive (crashworthiness) and active safety. } \\
\text { - ASEAN NCAP has also introduced Child } \\
\text { Occupant Protection (COP) star rating. }\end{array}$ \\
\hline \multirow{3}{*}{$\begin{array}{l}\text { (C4) } \\
\text { Advocacy \& } \\
\text { Education }\end{array}$} & $\begin{array}{l}\text { (P6) Helmet } \\
\text { Program }\end{array}$ & $\begin{array}{l}\text { - Helmet is the most important protection for } \\
\text { motorcyclist in the case of falling/impact. } \\
\text { - Wearing rate and proper usage is the main concern } \\
\text { (to be discussed). }\end{array}$ \\
\hline & $\begin{array}{l}\text { (P7) Driver } \\
\text { Training }\end{array}$ & $\begin{array}{l}\text { - The main aim is to increase the standard and to } \\
\text { enhance training and testing method. } \\
\text { - Faced long delay due to costing issues and was } \\
\text { only fully introduced in } 2014 \text {. }\end{array}$ \\
\hline & $\begin{array}{l}\text { (P8) Road Safety } \\
\text { Education (RSE) } \\
\text { \& Community } \\
\text { Based Program } \\
\quad \text { (CBP) }\end{array}$ & $\begin{array}{l}\text { - RSE was introduced as pilot projects in } 2007 \text {; } \\
\text { national rollout in } 2010 \text {. } \\
\text { - CBP to inculcate advocacy efforts - "by the } \\
\text { people, for the people". } \\
\text { - RSE and CBP will complement Driver Training } \\
\text { (P7); the RSE is a long-term "investment" while } \\
\text { CBP requires strong political will. }\end{array}$ \\
\hline
\end{tabular}


Table 3. Road transportation related functions of Malaysian Government agencies.

\begin{tabular}{|c|c|}
\hline Ministry & $\begin{array}{c}\text { Agency/Department with } \\
\text { Road Transportation Related Functions }\end{array}$ \\
\hline \multirow{3}{*}{$\begin{array}{l}\text { Min. of } \\
\text { Transport } \\
\text { (MOT) }\end{array}$} & $\begin{array}{l}\text { Road Transport Dept. }(\text { RTD/JPJ }) \text { - Undertaking registration and } \\
\text { licensing of drivers and all motor vehicles and trailers; } \\
\text { enforcement and regulatory duties according to Road Transport } \\
\text { Act (RTA). }\end{array}$ \\
\hline & $\begin{array}{l}\text { Road Safety Dept. }(\text { RSD/JKJR }) \text { - Conducts road safety advocacy } \\
\text { to increase awareness of road users on the importance of road } \\
\text { safety. }\end{array}$ \\
\hline & $\begin{array}{l}\text { MIROS - Conducts research and evidence-based intervention } \\
\text { programs; provide basis for the formulation of new strategies, } \\
\text { legislations, policies, and enforcement measures at national level. }\end{array}$ \\
\hline $\begin{array}{l}\text { Min. of Home } \\
\text { Affairs (KDN) }\end{array}$ & $\begin{array}{l}\text { The Royal Malaysia Police }(\boldsymbol{R M P} / \boldsymbol{P D R M})-\text { A centralised } \\
\text { organisation with responsibilities ranging from traffic control to } \\
\text { intelligence gathering. (Traffic Police Contingent) }\end{array}$ \\
\hline $\begin{array}{l}\text { Prime Minister } \\
\text { Dept. (PMD) }\end{array}$ & $\begin{array}{l}\text { Land Public Transport Commission }(S P A D) \text { - Drawing up } \\
\text { policies, planning and regulating all aspects of train, bus and taxi } \\
\text { services as well as road- and rail-based freight transport. }\end{array}$ \\
\hline \multirow{2}{*}{$\begin{array}{l}\text { Min. of Int. } \\
\text { Trade \& } \\
\text { Industry (MITI) }\end{array}$} & $\begin{array}{l}\text { MITI determines the policies and direction to achieve the goals of } \\
\text { international trade and industries (including the automotive sector). }\end{array}$ \\
\hline & $\begin{array}{l}\text { Malaysia Automotive Institute (MAI) - Provides advisory and } \\
\text { assistance in formulating strategies and policies to ensure growth } \\
\text { and sustainability of Malaysia's automotive industry. }\end{array}$ \\
\hline $\begin{array}{l}\text { Min. of Finance } \\
\text { (MOF) }\end{array}$ & $\begin{array}{l}\text { Royal Malaysian Customs (RMC/JKDM) - Responsible for } \\
\text { administrating the nation's indirect tax policy, border enforcement } \\
\text { and narcotics offences. (including automotive and safety items) }\end{array}$ \\
\hline $\begin{array}{l}\text { Min. of } \\
\text { Science, Tech. } \\
\& \text { Innovation } \\
\text { (MOSTI) }\end{array}$ & $\begin{array}{l}\text { Dept. of Standards Malaysia (Standards Malaysia) - The sole } \\
\text { national standards and accreditation body of Malaysia. }\end{array}$ \\
\hline $\begin{array}{l}\text { Min. of Works } \\
\text { (KKR) }\end{array}$ & $\begin{array}{l}\text { Public Works Dept. }(\boldsymbol{P W D} / J K R) \text { - JKR's Roads Branch is } \\
\text { responsible for building and maintaining roads in Malaysia such as } \\
\text { federal roads, state roads, bridges, interchanges, etc. }\end{array}$ \\
\hline \multirow{2}{*}{$\begin{array}{l}\text { Min. of } \\
\text { Domestic } \\
\text { Trade, Co-Op. } \\
\text { \& Consumerism } \\
\text { (KPDNKK) }\end{array}$} & $\begin{array}{l}\text { KPDNKK formulates policies, strategies and reviews matters } \\
\text { related to the development of domestic trade and consumerism } \\
\text { (including enforcement under the Enforcement Dept.). }\end{array}$ \\
\hline & $\begin{array}{l}\text { Tribunal For Consumer Claims Malaysia - Provides an } \\
\text { alternative forum for consumers to file claims in a simple, } \\
\text { inexpensive and speedy manner. }\end{array}$ \\
\hline $\begin{array}{l}\text { Min. of Urban } \\
\text { Wellbeing, } \\
\text { Housing \& } \\
\text { Local Gov. } \\
\text { (KPKT) }\end{array}$ & $\begin{array}{l}\text { All Local Government/Local Council (Malay: Pihak Berkuasa } \\
\text { Tempatan - PBT) - City Hall or City Council; Municipal Council; } \\
\text { District Council; Special \& Modified Local Council; responsible } \\
\text { for certain road traffic matters for the area under their jurisdiction. }\end{array}$ \\
\hline
\end{tabular}




\section{Legislative Framework}

By and large, the creation of laws in Malaysia with regard to road transport and safety matters is under the purview of the Ministry of Transport (MOT), with agencies such as the Road Safety Department (RSD), RTD and MIROS working together in realising the enactment of new laws as well as reviewing those already in existence. RTD is responsible for enforcing laws according to Road Transport Act (RTA; Act 333) (1987) with significant emphasis on licensing and vehicle related matters [37]. It is perhaps only unique to Malaysia that part of the RTA is also executed by the police (RMP) when it comes to enforcement matters with the Traffic Police Contingent being responsible for traffic management and enforcement, including road accident investigations. In addition to that, the newly established Land Public Transport Commission (SPAD; taking over the jurisdiction of preceding agency - the Commercial Vehicles Licensing Board (CVLB) for the West Malaysia region) regulates and enforces rules concerning land-based public and freight transport in Malaysia.

Most of the country's governmental and legal matters are managed and enforced through the federal government, and this can be compared with several countries that are more state-oriented in handling the road transportation matters. From another perspective, more ministries and their agencies have been directly or indirectly involved in road transportation matters as explained in Table 3. The list may not be comprehensive to show other functions in Malaysia's road transportation system by other agencies or ministries (e.g. Ministry of Health; Ministry of Education; Ministry of Tourism), but is sufficient to show the complexity of the process for any initiative to be successful. The integration at the governmental level, in the case of new or revised laws, needs to be efficiently communicated and executed at all relevant levels.

The safety items' current law requirements are as follows:

(i) Seatbelt. Seatbelt wearing has been made mandatory for the front occupants since 1979 and among the earliest study conducted on taxi drivers in 1993 revealed that the compliance rate was about $40 \%[22,38]$. The rear seatbelt law was introduced 30 years later, coming into effect on the $1^{\text {st }}$ of January 2009, in which a nationwide advocacy campaign was launched six months prior to the effective date of enforcement [22].

(ii) Child Safety Seat. Malaysia has yet to implement child seat law [39, 40], although there are positive signs of support from the public after tragic cases involving child deaths (e.g. plunged out of car) had caught people's attention thanks to 'viral' news shared through social media by Malaysians. The Ministry of Transport is also planning to regulate the usage of CSS in passenger cars by 2017 through amendment of RTA [9]. Additionally, road users' concern regarding CSS usage is believed to be influenced by the automobile safety rating programme, ASEAN NCAP, in which the programme had introduced specific rating for children protection in car crashes, namely the Child Occupant Protection (COP) rating [41].

(iii) Helmet. Helmet wearing has been made compulsory for motorcyclist since the early seventies, following historical completion of the country's first Malaysian Standard (MS 1) in 1969 [34]. The law in Malaysia allows only one pillion passenger but without mentioning the minimum age for the passenger, therefore raising question as regard the child pillion [13]. 


\section{Related Research Findings - Observational Studies}

Figure 2 shows the progress of seatbelt wearing compliance from few selected studies in order to gauge users' awareness to wear seatbelt although the law has long been put in place. As mentioned earlier, a brief study by Hauswald in 1993 on a small population of taxi drivers revealed the compliance rate of $40 \%$ [38]. A more comprehensive study carried out by Kulanthayan et al. ten years later showed compliance rate for drivers and front occupants at $76 \%$ and $56 \%$ respectively [42]. Norlen et al. of MIROS, had conducted multiple studies on seatbelt wearing and several studies have been selected to show the impact of rear seatbelt law introduced in [22, 43, 44]. It is clear that rear seatbelt wearing is still low after about six years since the enforceable date, as supported by the latest findings by Aqbal et al. (2014) and Wahida et al. (2015) [11, 27]. A spike only occurred in the earlier months of rear seatbelt law introduction, in which the result was derived from a nationwide level study. In the case of drivers and front passengers, the results are less than satisfactory. The former can be considered "good" but more efforts are needed to convince the front passengers.

Furthermore, study on CSS is quite limited in the context of Malaysia - a sign that this safety item is still new to road users as a whole (Figure 3). Kulanthayan et al. (2004) was the first to conduct a "reality check" in the state of Melaka but his study was only limited to availability of CSS (at least one) in the observed vehicles [39]. More recent studies on CSS were conducted by Muammar et al. (2012) and Sharina et al. (2015) of MIROS, in which both studies confirmed that CSS usage was still very low i.e. below $10 \%$ with the latter revealing only $2.4 \%$ usage rate among 2,230 observed samples $[9,45]$.

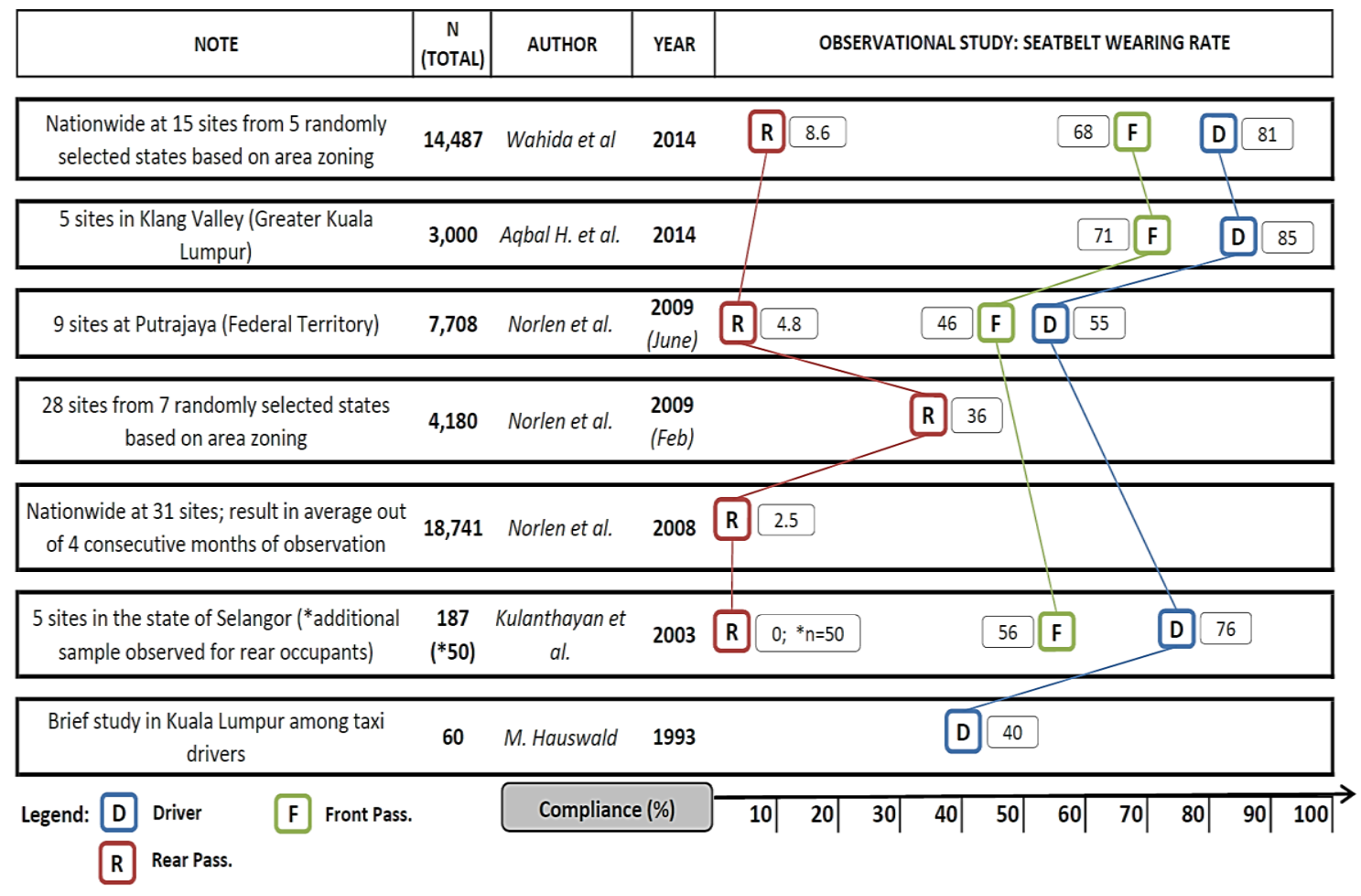

Figure 2. Seatbelt compliance from selected observational studies. 


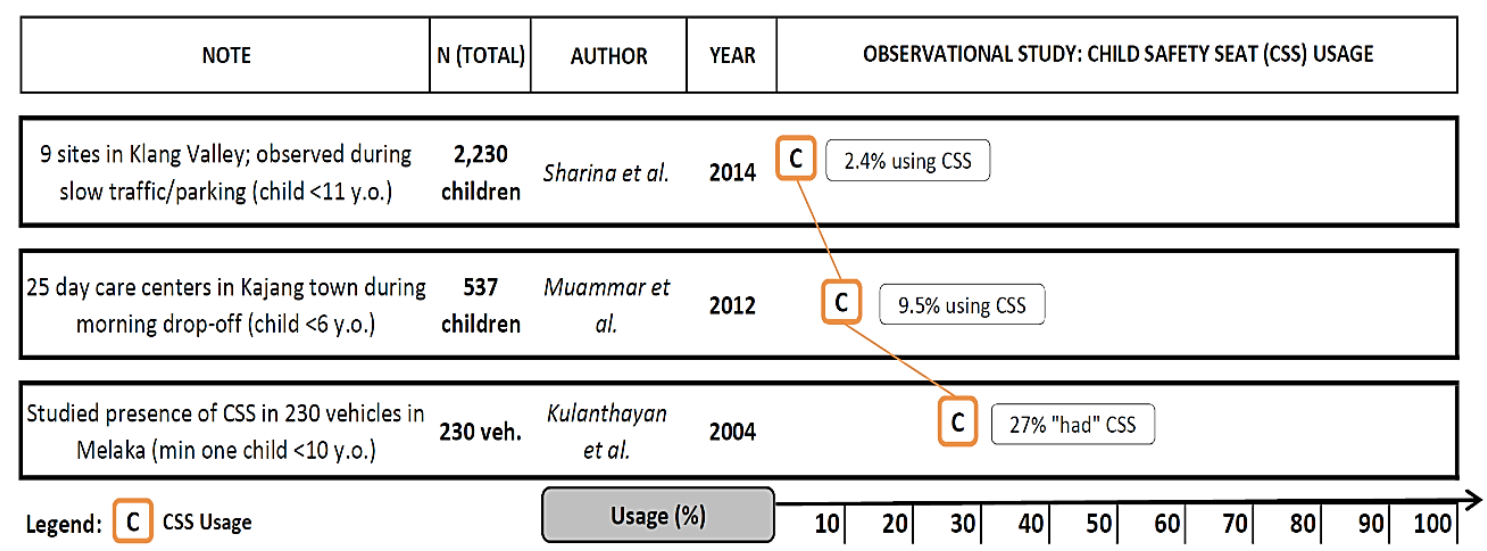

Figure 3. CSS usage from available observational studies.

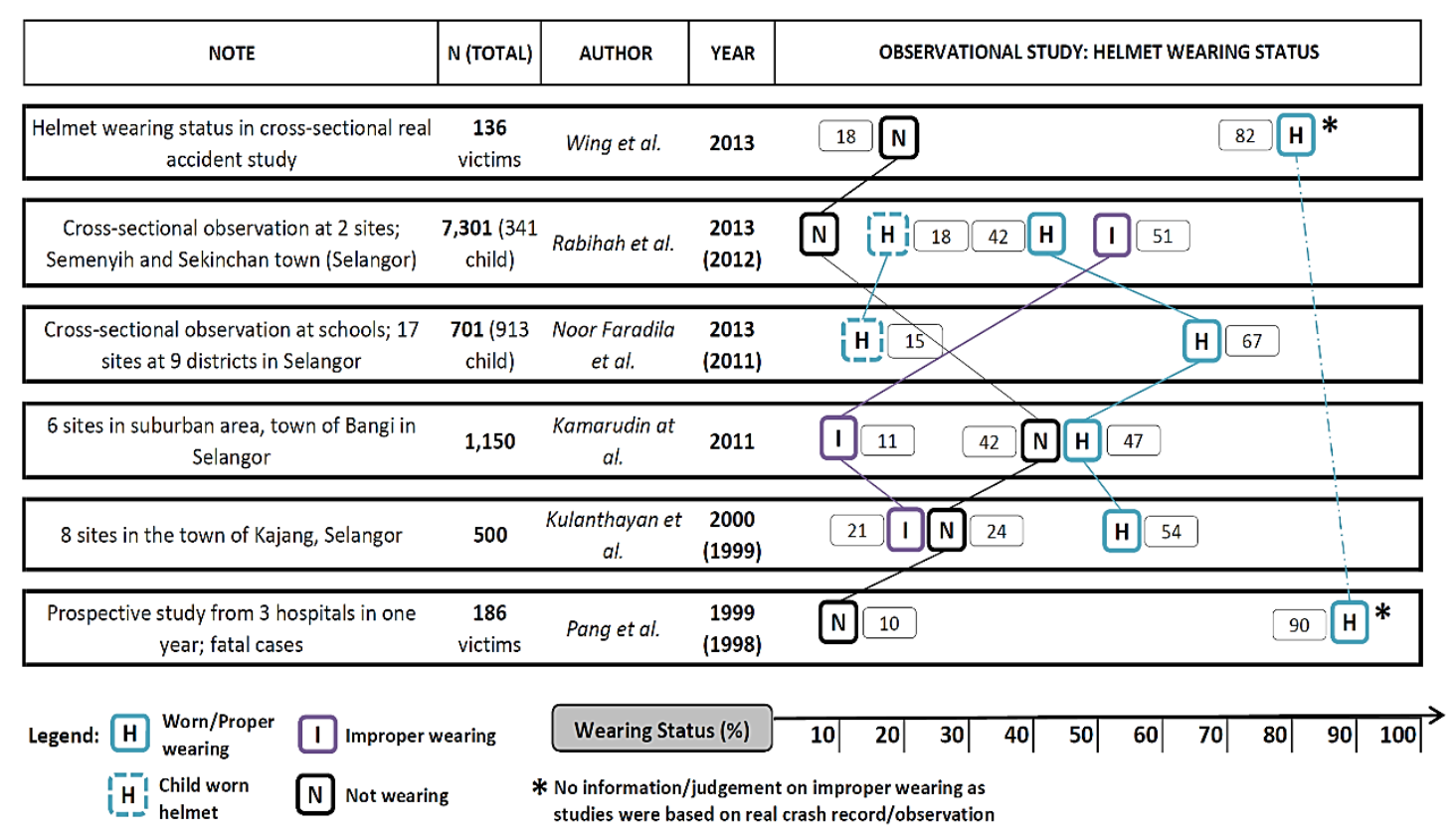

Figure 4. Helmet usage from selected observational studies.

In addition, helmet wearing compliance seems way below satisfactory level although being the earliest to be mandated by law - a problem compounded by the fact that improper wearing is also a prominent issue (Figure 4). Compared to seatbelt wearing, most motorcyclists do not place importance on helmet as their only protection, especially in the suburban and rural areas $[10,14,46]$. The compliance rate was observed as low as $42 \%$, with another $51 \%$ not properly wearing their helmet, even during festive seasons when enforcement activities are intensely carried out in the country [27]. Helmet for the child occupant poses a more serious concern, as the study by Noor Faradila et al. (2013) and Rabihah et al. (2013) confirmed that the wearing rate is still low [27, 46]. However, 'child as pillion' as well as the helmet efficacy for them requires another level of discussion as reported by Noor Faradila et al. (2013) and Azhar et al. (2009) as it is more related to socioeconomic and sociotechnical aspects rather than merely legislative [13, 46]. Studies by Pang et al. (1999) and Wing et al. (2014), found higher compliance rates since their studies had made no remarks on improper wearing i.e. the victims found with helmet were considered helmeted [47, 48]. 


\section{The Way Forward}

In a country experiencing rapid development phase, with Malaysia aiming to become a developed nation soon, road safety must be given utmost priority as the entire road transportation system is struggling to strike a balance between exposures (transport demand) and risks (safe operation) [20]. Admittedly, the number of exposures will significantly increase. In order to reach the desired sustainability level, a more creative solution is needed to reduce the number of road deaths. The ultimate goal is to achieve a state of self-driven attitude towards the use of safety items among road users. Relying on the law can be considered as "basic" since enforcement will encounter many challenges such as limited resources, with "compliance" still based on enforcement visibility. A frequent study by MIROS on the perception of being caught (POBC), proved that road users' POBC will increase during the intense period of enforcement, which is usually overt in nature during festive seasons in Malaysia (celebration of Eid Fitr, Chinese New Year, Christmas/year end school holidays) [49, 50].

Therefore, it is high time to turn to other solutions such as the use of technology to influence or force road users to wear safety items. SBR is one of the examples, whereby a study by Aqbal et al. (2014) has shown that drivers in vehicles fitted with SBR were two times more likely to wear seatbelt than those in vehicles without, and wearing rates were higher for audiovisual SBR than those with visual-only reminder - a sign that there is a way to increase the likelihood of wearing by embedding an additional feature. For CSS, it is quite obvious that the law has to be in place in order to proceed to the next level. Users' readiness (technology acceptance) may still pose a big question mark but from observations, the CSS can be easily acquired in the market and will become more popular among parents. In the case of crash helmet, improvement in the design to increase usage rate may not be an option because the awareness and willingness to wear helmet lies solely in the hands of motorcyclists. All in all, a purely systemic solution is needed for all the safety items especially in the case of helmet, whereby a state of self-driven can be achieved through prolonged efforts e.g. in business' systems (company policy for road safety mandatory compliance), standards requirements, as well as societal approach through effective advocacy programs.

\section{CONCLUSIONS}

This review has looked into the current situation pertaining to the usage of safety items, namely seatbelts and CSS for car occupants and helmet for motorcyclists, among private vehicle users in Malaysia. Though these safety items are important to protect users from the impact of road crashes, Malaysia's road users still display a lackadaisical attitude towards them. It is worrying to note that road users in Malaysia are taking their safety for granted although Malaysia remains as one of the riskiest countries in the world based on previous road safety records. This 'below than satisfactory compliance level' attitude is apparently a threat to Malaysia's road transportation system sustainability. Therefore, a more comprehensive systemic solution is needed for each case of the discussed safety items.

\section{ACKNOWLEDGEMENTS}

The authors would like to thanks to Malaysian Institute of Road Safety Research (MIROS), Malaysia for financial assistance and laboratory facilities. 


\section{REFERENCES}

[1] WHO. Global status report on road safety 2013: supporting a decade of action: World Health Organization; 2015.

[2] Lakkam S, Koetniyom S. Investigation of accident scenarios between pedestrians and city buses in Thailand. International Journal of Automotive and Mechanical Engineering. 2015;12:3076-88.

[3] Siam MFM, Isa MHM, Borhan N, Voon ASWS. Measurement of driver distraction in malaysia's traffic environment: A driving simulator study. Journal of Mechanical Engineering and Sciences. 2015;8:1472-80.

[4] Sarani R, Rahim S, Marjan JM, Voon W. Predicting Malaysian road fatalities for year 2020. Proc 4th International Conference on Road Safety and Simulations. 2012;23-5.

[5] RMP. RMP Annual Accident Statistics 2013. Kuala Lumpur; 2014.

[6] RMP. RMP Annual Accident Statistics 2015. Royal Malaysian Police; 2016.

[7] Ismail A, Abdullah S, Abdullah A, Deros BM. Whole-body vibration exposure of Malaysian taxi drivers. International Journal of Automotive and Mechanical Engineering. 2015;11:2786-92.

[8] Siti Nur Atikah A, Abdul Adam A, Ahmad Rasdan I. A Descriptive analysis of factors contributing to bus drivers' performances while driving: A case study in Malaysia. International Journal of Automotive and Mechanical Engineering. 2015;11:2430-7.

[9] Håland Y. The evolution of the three point seat belt from yesterday to tomorrow. Proceedings of the International Research Council on the Biomechanics of Injury conference: International Research Council on Biomechanics of Injury; 2006.

[10] Mohd Ariffin M, Mohd Soid N, Borhan N, Sukardi A. The prevalence of child restraint system use among children in vehicles equipped with front passenger airbag in Kajang, Malaysia. Applied Mechanics \& Materials; 2014.

[11] Kulanthayan S, Umar RR, Hariza HA, Nasir MM, Harwant S. Compliance of proper safety helmet usage in motorcyclists. Medical Journal of Malaysia. 2000;55:40-4.

[12] Ameer Batcha W, Othman I, Azhar A, Alias NK, Ahmad MS, Tan CY. Nationwide roadside observation of safety seatbelt wearing rate among vehicle occupants in Malaysia. Malaysian Institute of Road safety Research; 2015. p. 239-44.

[13] S. T. Government aims for child car seat regulation by 2017. The Sun Daily; 2015.

[14] Hamzah A, Ahmad Y, Voon WS. Child helmet efficacy for motorcycle use in Malaysia; 2010.

[15] Ambak K, Ismail R, Abdullah RA, Borhan MN. Using structural equation modeling and the behavioral sciences theories in predicting helmet use. International Journal on Advanced Science, Engineering and Information Technology. 2011;1:639-45.

[16] Hizal Hanis H, Sharifah Allyana S. The construction of road accident analysis and database system in Malaysia. 14th IRTAD Conference: Citeseer. 2009;16-7.

[17] Jawi ZM, Abidin ANSZ, Ghani Y, Osman MR. News and Newsworthiness Factor in In-Depth Crash Investigation and Reconstruction. Asian Road Safety. Kuala Lumpur. 2015;290-7. 
[18] Chiu W-T, Kuo C-Y, Hung C-C, Chen M. The effect of the Taiwan motorcycle helmet use law on head injuries. American journal of public health. 2000;90:793.

[19] Radin Umar R. Integrated approach to road safety in Malaysia. Malaysian Road Conference, 7th, 2007, Kuala Lumpur, Malaysia; 2007.

[20] Sarani R, Hashim HH, Yaakob WFW, Mohamed N, Sohadi RUR. The effect of rear seatbelt advocacy and law enforcement in reducing injuries among passenger vehicle occupants in Malaysia. International Journal of Public Health Research. 2013;3:267-75.

[21] Scott-Parker B, Goode N, Salmon P, Senserrick T. Knowing me knowing you: key players and their interactions within the young driver road safety system. Safety Science. 2016;88:88-96.

[22] SWOV. Seat belts and child restraint seats. Leidschendam, the Netherlands: SWOV; 2010.

[23] Mohamed N, Yusoff M, Batcha W, Othman I, Abdullah I. Seatbelt wearing compliance among road users in Putrajaya; 2010.

[24] Elvik R, Høye A, Vaa T, Sørensen M. The handbook of road safety measures: Emerald Group Publishing Limited; 2009.

[25] Evans L, Frick MC. Safety belt effectiveness in preventing driver fatalities versus a number of vehicular, accident, roadway, and environmental factors. Journal of Safety Research. 1987;17:143-54.

[26] Shimamura M, Yamazaki M, Fujita G. Method to evaluate the effect of safety belt use by rear seat passengers on the injury severity of front seat occupants. Accident Analysis \& Prevention. 2005;37:5-17.

[27] Paiman NF, Syazwan SM, Aqbal Hafeez A, Isa M, Hafzi M, Mohd Khairudin R, et al. Prevalence of carrying multiple pillion riders on the route to school. Advanced Engineering Forum. 2013;351-6.

[28] Ariffin AH, Solah MS, Hamzah A, Paiman NF, Isah N, Mohd Jawi Z, et al. Seatbelt reminder (SBR) system inclusion in ASEAN New Car Assessment Programme (ASEAN NCAP) rating: Supportive findings from a case study in Klang Valley, Malaysia. Australian Journal of Basic \& Applied Science. 2014;8:136-43.

[29] Elliott MR, Kallan MJ, Durbin DR, Winston FK. Effectiveness of child safety seats vs seat belts in reducing risk for death in children in passenger vehicle crashes. Archives of Pediatrics and Adolescent Medicine. 2006;160:617-21.

[30] Lund UJ. The effect of seating location on the injury of properly restrained children in child safety seats. Accident Analysis and Prevention. 2005;37:435-9.

[31] Durbin DR, Chen I, Smith R, Elliott MR, Winston FK. Effects of seating position and appropriate restraint use on the risk of injury to children in motor vehicle crashes. Pediatrics. 2005;115:e305-e9.

[32] Smith KM, Cummings P. Passenger seating position and the risk of passenger death or injury in traffic crashes. Accident Analysis and Prevention. 2004;36:25760 .

[33] Hamilton-Vaughan A. Free Child Restraint Checking Day Program: Behavioural change methodologies and practical implementation for Road Safety. Proc of the Aust Road Safety Research, Policing \&andEducation Conference; 2010.

[34] Daniels WL. A review of current technology in child safety seats for infants. Journal of Pediatric Health Care. 2006;20:419-23. 
[35] Kulanthayan S, Radin Umar R, Ahmad Hariza H, Mohd Nasir M. Modeling of compliance behavior of motorcyclists to proper usage of safety helmets in Malaysia. Traffic Injury Prevention. 2001;2:239-46.

[36] Liu BC, Ivers R, Norton R, Boufous S, Blows S, Lo SK. Helmets for preventing injury in motorcycle riders. The Cochrane Library. 2008.

[37] Jawi ZM, Isa MHM, Kassim KAA. Developed Nation in 2020: Malaysia's Road Safety and Modernization Threats. Nation.1:2.

[38] Jawi ZM, Deros BM, Osman MR, Awang A. A Systemic Overview on Driver Training and Driver Licensing System in Malaysia. ASEAN Road Safety Kuala Lumpur; 2015.

[39] Mohamed N, Voon WS, Hashim HH, Othman I. An overview of road traffic injuries among children in Malaysia and its implication on road traffic injury prevention strategy; 2011.

[40] Hauswald M. Seat belt use in a developing country: covert noncompliance with a primary enforcement law in Malaysia. Accident Analysis and Prevention. 1997;29:695-7.

[41] Kulanthayan S, Razak A, Schenk E. Driver characteristics associated with child safety seat usage in Malaysia: A cross-sectional study. Accident Analysis and Prevention. 2010;42:509-14.

[42] Syazwan SM, Hafzi M, Azhar H, Hafeez AA, Yahya A, Zulhaidi M, et al. Assessment of Child Occupant Protection in ASEAN NCAP. Applied Mechanics and Materials. 2014.

[43] Kulanthayan S, Law T, Raha A, RADIN UR. Seat belt use among car users in Malaysia. IATSS Research. 2004;28:19-25.

[44] Mohamed N, Fadhli M, Isah N, Othman I, Faradila N, Mansor F. Phase 1: achievements of first 3-month advocacy program: rear seatbelt use: public awareness and practice; 2008.

[45] Mohamed N, Isah N, Yussof F. Rear Sseatbelt usage in Malaysia: findings from roadside observations and surveys. International Journal of Public Health Research. 2011;1:48-54.

[46] Shariff S, Borhan N, Ali A. An Observation Study: CRS Use in Vehicles Among Children Aged 0-11 in Klang Valley, Kuala Lumpur.

[47] Rabihah I, Azli A, Abdullah S, Nurulhana B. Enforcement and Helmet Use Compliance: An Observation in Selected Areas in Selangor. Proc of 4th International Conference for Road Safety; 2013.

[48] Pang T, Radin Umar R, Azhar A, Harwant S, Shahrom A, Halim A, et al. Fatal injuries in Malaysian motorcyclists. International Medical Research Journal. 1999;3:115-9.

[49] Abdul Manap AR, Ab Rasid AA, Alvin Poi WH, Syed Md Rahim SA, Mohd Jawi Z, Radin Sohadi RU. OPS Bersepadu - Conducted over the Chinese New Year Period from 11-25 February 2007. Malaysian Institute of Road Safety Research; 2007.

[50] Mohd Yusoff MF, Pillai S, Radin Sohadi RU. OPS Bersepadu - Conducted over the Hari Raya Period from 7-21 October 2007. Malaysian Institute of Road Safety Research; 2007. 